\title{
PRIORITAS SOLUSI PERMASALAHAN PENGELOLAAN ZAKAT DENGAN METODE AHP (STUDI DI BANTEN DAN KALIMANTAN SELATAN)
}

\author{
Nurul Huda, Desti Anggraini, Khalifah Muhamad Ali \\ Yosi Mardoni, Nova Rini ${ }^{1}$
}

\begin{abstract}
The Priority Problems and Solutions of Zakab Management in Banten and South Borneo Using AHP. The aim of this study is to map the priority problems and solutions in the management of zakat by using AHP (Analytic Hierarchy Process). Results of a study reveals that there are three kinds of priority issues and solutions zakat management divided by stakeholder agencies (stakeholders) zakat, i.e regulators, zakat organization (OPZ), muzaki and mustahik . The Analytical Hierarchy Process (AHP) model at Banten and Jakarta give a same priority score, i.e. the institution for solving problem in zakat management is OPS dan regulator solution priority is amil sertification.
\end{abstract}

Keywords: AHP, Problems, Solutions, Zakat

\begin{abstract}
Abstrak. Prioritas Solusi Permasalahan Pengelolaan Zakat di Propinsi Banten dan Kalimantan Selatan dengan Metode AHP. Penelitian ini bertujuan untuk memetakan prioritas masalah dan solusi dalam pengelolaan zakat dengan menggunakan metode AHP (Analytic Hierarchy Process). Hasil penelitian mengungkapkan bahwa terdapat tiga macam prioritas masalah dan solusi pengelolaan zakat yang dibagi berdasarkan lembaga pemangku kepentingan (stakeholder) pengelolaan zakat, yaitu regulator, organisasi pengelola zakat (OPZ), serta muzaki dan mustahik zakat. Model AHP di Banten dan Kalsel menghasilkan skor prioritas yang sama, bahwa lembaga yang paling diandalkan dalam pemecahan masalah pengelolaan zakat adalah OPZ dan prioritas solusi regulator adalah sertifikasi amil.
\end{abstract}

Kata Kunci: AHP, Masalah, Solusi, Zakat

\footnotetext{
${ }^{1}$ Diterima: 17 Maret, Direvisi: 15 April 2014 , Disetujui: 28 April 2014

Fakultas Ekonomi Universitas Yarsi, Jl. Letjen Suprapto Kav. 13, Cempaka Putih, Jakarta, Email: pakhuda@ yahoo.com

Pascasarjana Universitas Indonesia KajianTimur Tengah dan Islam, Jl. Salemba Raya 4, Jakarta. Email: saghi_sharia@yahoo.co.uk; Email: kangkhalifah@yahoo.co.id, Email mardoni3003@yahoo.co.id STIE Muhammadiyah Jakarta, Jl. Minangkabaru Barat, No.60, Jakarta. Email: nvrin207@yahoo.com
} 


\section{PENDAHULUAN}

Permasalahan kemiskinan sampai saat ini merupakan isu yang menarik untuk dibahas. Berbagai macam program dan solusi yang sudah dilakukan oleh pemerintah maupun swadaya masyarakat, kemiskinan masih belum mengalami penurunan. Salah satu solusi mengatasi kemiskinan tersebut adalah dengan sistem ekonomi Islam. Sistem ekonomi Islam yang sudah berkembang saat ini adalah mengenai perbankan dan lembaga keuangan syariah. Meskipun isu perbankan dan lembaga keuangan syariah telah menerima perhatian yang paling banyak, para informan penelitian menilai bahwa isu perbankan dan lembaga keuangan syariah bukanlah isu yang paling prioritas. Perbankan syariah dinilai belum bisa memecahkan masalah yang sangat mendasar di dalam negara-negara Islam, yaitu kemiskinan dan rendahnya tingkat pendidikan (Abduh: 2013). Selain isu mengenai perbankan dan lembaga keuangan syariah untuk mengatasi kemiskinan, instrument lain dalam sistem ekonomi Islam yang dapat digunakan sebagai solusi kemiskinan adalah instrumen zakat. Beberapa kajian yang dilakukan Beik (2009), Tsani (2010), Hartoyo dan Purnamasari (2010), dan Anriani (2010) mengungkapkan bahwa zakat terbukti mampu mengurangi jumlah dan persentase keluarga miskin, serta mengurangi kedalaman dan keparahan kemiskinan.

Meskipun dianggap sebagai terpenting dalam area ilmu ekonomi dan keuangan Islam, zakat belum menerima perhatian yang cukup dari kalangan intelektual muslim terutama dalam bidang riset-riset yang terkait dengan pengembangan pengelolaan zakat. Padahal pada kenyataannya masih banyak kelemahan yang ada pada pengelolaan zakat. Meskipun penghimpunan zakat terus meningkat dari tahun ke tahun, realisasi penghimpunan zakat nasional masih jauh dari potensi yang ada. Pada tahun 2011, total penghimpunan zakat belum mencapai satu persen dari total potensi yang ada (Baznas dan FEM IPB: 2011).

Saat ini masih banyak propinsi di Indonesia yang memiliki angka kemiskinan cukup tinggi. Berdasarkan Peta Kemiskinan tahun 2010 yang memetakan sebaran mustahik, muzaki, dan potensi zakat setiap provinsi di Indonesia, provinsi Banten dan Kalimantan Selatan merupakan provinsi yang dihuni oleh muzaki dan mustahik dengan jumlah yang seimbang, namun Banten memiliki potensi zakat yang tinggi sedangkan Kalsel memiliki potensi zakat yang rendah.

Karakter propinsi Banten dan Kalimantan Selatan tersebut menarik peneliti untuk melakukan penelitian mengenai prioritas solusi permasalahan zakat. Penelitian ini akan memetakan prioritas masalah pengelolaan zakat dan mencari prioritas solusinya. Salah satu metode yang paling populer dalam pemetaan masalah dan solusi adalah metode Analytic Hierarchy Process (AHP). Berdasarkan uraian di atas, dapat disusun pertanyaan penelitian sebagai berikut: 1) Apa prioritas masalah 
dalam pengelolaan zakat? ; 2) Apa prioritas solusi yang dapat diberikan atas prioritas masalah tersebut?;dan 3) Bagaimana perbandingan prioritas masalah pengelolaan zakat di provinsi Banten dan Kalimantan Selatan?

\section{TINJAUAN PUSTAKA}

Sabiq (2006) menyatakan bahwa zakat merupakan nama dari sesuatu hak Allah yang dikeluarkan kepada yang berhak menerima zakat (mustahik). Dinamakan zakat dikarenakan mengandung harapan untuk mendapatkan berkah, membersihkan, dan memupuk jiwa dengan berbagai kebaikan. Zakat merupakan salah satu dari lima rukun Islam dan disebutkan secara beriringan dengan kata shalat pada 82 ayat di dalam Al Qur'an. Sementara menurut Qardhawi (2007), zakat secara fikih berarti sejumlah harta tertentu yang diwajibkan Allah untuk diserahkan kepada orang-orang yang berhak. Allah telah menetapkan hukum wajib atas zakat sebagaimana dijelaskan di dalam Al Qur'an, Sunnah Rasul, dan ijma' ulama kaum muslimin. Hukum menunaikan zakat adalah wajib bagi setiap muslim yang telah memenuhi kriteria.

Indrijatiningrum melakukan penelitian mengenai persoalan utama zakat. Hasil penelitian Indrijatiningrum (2005) menyatakan bahwa beberapa persoalan utama zakat adalah gap yang sangat besar antara potensi zakat dan realisasinya, hal ini disebabkan masalah kelembagaan pengelola zakat dan masalah kesadaran masyarakat, serta masalah sistem manajemen zakat yang belum terpadu. Untuk mengatasi masalah tersebut, perlu dilakukan strategi yang dapat mengatasi ancaman dan tantangan yang dihadapi dan memperbaiki kelemahan OPZ secara keseluruhan. Prioritas kebijakan yang perlu dilakukan yaitu penerapan sanksi bagi muzaki yang tidak berzakat, meningkatkan kualitas sumber daya manusia untuk meningkatkan keprofesionalisme, kredibilitas, akuntabilitas, dan transparansi OPZ; dan mensinergikan pelaksanaan sistem pajak dan zakat secara nasional. Skenario terbaik dalam meningkatkan potensi zakat adalah melalui reformasi perundangundangan (Indrijatiningrum: 2005).

Chalikuzhi (2009) dalam disertasinya menyatakan beberapa isu utama pengelolaan zakat: (1) Rendahnya pengetahuan zakat yang berakibat tidak ketidakefektifan pengumpulan zakat, hal ini berimplikasi perlunya sosialisasi zakat guna meningkatkan kesadaran membayar zakat; (2) Rendahnya keimanan juga mempengaruhi ketidakefektifan pengumpulan zakat; (3) Perbedaan pandangan terhadap fikih zakat juga merupakan faktor penghambat ketidakoptimalan penghimpunan zakat; (4) Faktor transparansi yang masih rendah dari lembaga zakat berimplikasi terhadap rendahnya pembayaran zakat pada lembaga zakat. 
Mintarti (2012) menyatakan bahwa salah satu masalah utama dalam pengelolaan zakat adalah masih lemahnya sumberdaya manusia (SDM) amil. Kebanyakan amil tidak menjadikan pekerjaannya sebagai profesi atau pilihan karir, tapi sebagai pekerjaan sampingan atau pekerjaan paruh waktu.

\section{METODE}

Metode analisis yang digunakan dalam penelitian ini adalah metode AHP. Orang pertama yang mengembangkanAnalytic Hierarchy Process (AHP) adalah Thomas L Saaty. Saaty (2008) mengatakan bahwa, "The Analytic Hierarchy Process (AHP) is a theory of measurement through pairwise comparisons and relies on the judgements of experts to derive priority scales. "AHP adalah sebuah teori pengukuran melalui perbandingan berpasangan yang bergantung kepada penilaian para pakar yang dapat menghasilkan skala prioritas.

Saaty (1991), menyatakan bahwa penyelesaian masalah dengan AHP terdapat beberapa prinsip dasar, yaitu: Decomposition, Comparative Judgement, dan Synthesis of Priority. Decomposition artinya memecah persoalan yang utuh menjadi unsur-unsurnya sampai tidak mungkin dilakukan pemecahan lebih lanjut, sehingga didapatkan beberapa tingkatan dari persoalan tersebut. Comparative judgement adalah melakukan perbandingan antar elemen-elemen dalam hirarki yang disajikan dalam bentuk matriks. Perbandingan ini dilakukan dengan cara berpasangan antar elemen. Cara ini disebut juga pairwise camparation. Sementara itu hasil akhir dari seluruh prioritas adalah melakukan Synthesis of Priority. Dengan demikian maka akan diperoleh prioritas masing-masing elemen. Ada tiga tahapan penelitian yang akan dilakukan. Tiga tahapan tersebut terlihat pada gambar 1 .

Gambar 1. Tahapan Penelitian

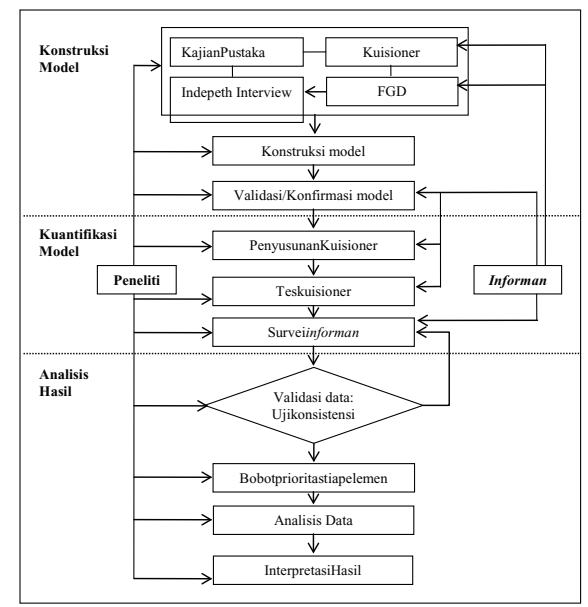




\section{Konstruksi Model}

Konstruksi model AHP disusun berdasarkan kajian pustaka secara teori maupun empiris. Penelitian ini melibatkan empat orang informan yang terdiri dari praktisi zakat. Dua orang informan diambil dari Provinsi Banten, dan dua informan lainnya dari Provinsi Kalimantan Selatan. Pemilihan daerah didasari oleh perbedaan potensi zakat dimana Banten memiliki potensi zakat yang tinggi sedang Kalimantan Selatan memiliki potensi zakat yang sedang. Perbedaan ini diharapkan dapat memberikan hasil penelitian yang lebih kaya dan beragam. Dalam tahapan konstruksi model ini para informan diajak untuk melakukan diskusi secara mendalam (in-depth interview).

\section{Kuantifikasi Model}

Tahap kuantifikasi model menggunakan pertanyaan dalam kuisioner berupa perbandingan berpasangan (pairwise comparison) antar elemen untuk mengetahui mana diantara keduanya yang lebih penting. Pengukuran dilakukan dengan skala numerik 1-9. Data hasil penilaian kemudian dikumpulkan dan input melalui software Superdecisions.

\section{Sintesis dan Analisis}

Sebelum data terolah dianalisis, akan dilakukan validasi data, yaitu dengan melakukan uji konsistensi. Data dianggap konsisten jika memiliki nilai rasionkonsistensi/consistency ratio (CR) <0.1 (Saaty: 1994). Jika nilai CR lebih besar dari 0,1, maka akan dilakukan penilaian (judgement) ulang oleh informan. Jika nilai CR telah konsisten, maka bobot prioritas elemen yang telah ada dapat digunakan sebagai dasar untuk analisis data dan interpretasi hasil.

\section{PEMBAHASAN}

Berdasarkan Peta Kemiskinan tahun 2010 yang memetakan sebaran mustahik, muzaki, dan potensi zakat setiap propinsi di Indonesia, propinsi Banten dan Kalimantan Selatan merupakan provinsi yang dihuni oleh muzaki dan mustahik dengan jumlah yang seimbang, namun Banten memiliki potensi zakat yang tinggi sedangkan Kalsel memiliki potensi zakat yang rendah.

Penelitian ini menemukan bahwa terdapat tiga macam prioritas masalah dan solusi pengelolaan zakat yang dibagi berdasarkan lembaga pemangku kepentingan (stakeholder) pengelolaan zakat, yaitu regulator, organisasi pengelola zakat (OPZ), dan masyarakat yang dalam hal ini didefinisikan sebagai muzaki dan mustahik zakat. Muzaki adalah orang yang membayar zakat, sedangkan mustahik adalah orang yang berhak menerima zakat. Hasil konstruksi model dibagi menjadi dua bagian, yaitu prioritas masalah dan prioritas solusi pengelolaan zakat. 


\section{Prioritas masalah pengelolaan zakat}

Prioritas masalah yang ada dalam regulator adalah: 1) perbedaan pendapat (khilafiyah) mengenai fiqih zakat; 2) rendahnya koordinasi antara regulator dengan OPZ; 3) rendahnya peran Kementerian Agama dalam pengelolaan zakat;dan 4) zakat belum menjadi obligatory system.

Salah satu contoh masalah khilafiyah fikih zakat adalah dalam pro-kontra zakat profesi. Sebagian ulama mendukung adanya zakat profesi, namun sebagian yang lain menganggap zakat profesi adalah bid'ah atau sesuatu yang diada-adakan dalam agama. Perbedaan pendapat dalam masalah fikih, termasuk fikih zakat, adalah sesuatu yang biasa dalam agama Islam, namun demikian agar umat Islam tidak bingung dan menghindari perpecahan, perlu ditetapkan satu pendapat yang diambil sebagai pegangan. Institusi yang dapat menyelesaikan masalah khilafiyah fikih zakat ini adalah pemerintah sebagai pemegang kekuasaan.

Prioritas masalah zakat selanjutnya adalah rendahnya koordinasi antara regulator zakat dengan OPZ. Sebagian OPZ, terutama OPZ besar bentukan masyarakat, cenderung memiliki egoisme organisasi yang juga besar. Sejarah panjang OPZ dalam membesarkan organisasinya memberikan pengaruh terhadap cara pandangnya terhadap memandang regulator.

Sebagian informan mengungkapkan bahwa salah satu prioritas masalah pengelolaan zakat lainnya adalah rendahnya peran Kementerian Agama (Kemenang) dalam pengelolaan zakat. Perhatian Kemenang terhadap zakat jauh lebih kecil dibandingkan perhatiannya terhadap pengelolaan haji. Kemenang menyerahkan urusan pengelolaan zakat kepada BAZNAS.

Prioritas masalah zakat terakhir adalah belumnya zakat menjadi obligatory system dalam sistem negara. Akibatnya kesadaran masyarakat dalam menunaikan zakat menjadi rendah. Seorang wajib zakat yang sudah mengetahui kewajiban zakat menjadi kurang terdorong untuk membayar zakat karena tidak adanya sanksi (punishment) ataupun insentif (reward) yang tetapkan oleh pemerintah.

Prioritas masalah pada OPZ adalah: 1) jumlah Lembaga Amil Zakat yang terlalu banyak; 2) mahalnya biaya promosi; 3) rendahnya efektifitas program pedayagunaan zakat; 4) rendahnya sinergi antar stakeholder zakat; dan 5) terbatasnya sumberdaya manusia (SDM) amil zakat.

Sebagian informan yang berasal dari OPZ pemerintah mengatakan bahwa salah satu prioritas masalah zakat adalah terlalu banyaknya OPZ bentukan masyarakat (LAZ). Menurut mereka zakat seharusnya dikelola oleh negara sebagaimana di zaman Rasulullah saw dimana zakat dikelola oleh baitul maal. Pertumbuhan LAZ yang cukup pesat dalam beberapa tahun terakhir dianggap sebagai ancaman 
terhadap sistem pengelolaan zakat nasional. Pertumbuhan kuantitas yang tidak diiringi dengan peningkatan kualitas dapat menjadi faktor yang dapat menurunkan tingkat kepercayaan masyarakat terhadap OPZ secara keseluruhan. Dari sekian banyak OPZ yang ada, baru $43 \mathrm{OPZ}$ yang terdaftar di Forum Zakat (FOZ) dan baru 12 OPZ diantaranya yang memiliki ijin dari pemerintah.

Prioritas masalah zakat selanjutnya adalah mahalnya biaya promosi. OPZ sebagai pengelola zakat memiliki satu peran utama yaitu penghimpunan dana zakat. Dalam aktivitasnya menghimpun dana dari masyarakat OPZ perlu melakukan promosi kepada masyarakat luas. Sebagai organisasi yang bersifat mandiri, OPZ harus membayar biaya promosi dari dana sendiri. Akibatnya biaya promosi diambil dari dana yang telah dikumpulkan dari masyarakat yang sebenarnya diharapkan oleh para muzaki dapat digunakan untuk membantu mustahik zakat terutama golongan fakir miskin.

Rendahnya efektifitas program pendayagunaan zakat dianggap sebagai prioritas masalah pengelolaan zakat. Efektifitas yang dimaksud adalah ketepatan dan kesinambungan program pendayagunaan zakat dalam memberikan kemaslahatan kepada mustahik. Masih banyak OPZ yang membuat program pendayagunaan zakat untuk sekedar pamer di media. Sehingga pada saat selesai diliput oleh media, program pendayagunaan berakhir.

Selain masih rendahnya sinergi antara OPZ dengan regulator, ternyata prioritas masalah juga ada pada lemahnya sinergi antara OPZ. OPZ yang telah berhasil membesarkan organisasinya masing-masing dianggap memiliki egoisme organisasi yang akhirnya sulit membuat organisasinya bekerja sama dengan OPZ lain. Kesamaan tujuan semua OPZ dalam memberikan kemaslahatan pada mustahik tidak serta merta membuat OPZ dapat bersinergi dengan baik. Padahal Allah swt telah memberikan arahan agar hamba-hamba-Nya dapat saling bersinergi dalam kebaikan dan ketaqwaan.

Prioritas masalah pada muzaki/mustahik adalah: 1) mustahik yang cenderung karikatif; 2) rendahnya kepercayaan muzaki kepada OPZ dan regulator; 3) rendahnya kesadaran muzaki dalam menunaikan zakat secara benar sesuai syariat; dan 4) rendahnya pengetahuan muzaki tentang fikih zakat.

Prioritas masalah pertama yang datang dari sisi muzaki/mustahik adalah mustahik yang cenderung karikatif atau konsumtif. Salah satu tujuan utama OPZ adalah mengubah status mustahik menjadi muzaki. Mustahik zakat yang masih mampu berusaha diberdayakan sedemikian rupa sehingga dapat mandiri dan hidup sejahtera. Namun demikian, banyak mustahik yang konsumtif. Dana zakat yang diberikan kepadanya untuk menjadi produksi justru digunakan untuk konsumsi. 
Akhirnya banyak program pemberdayaan yang mengalami kegagalan.

Prioritas masalah zakat yang berasal dari sisi muzaki/mustahik lainnya adalah rendahnya kepercayaan muzaki kepada OPZ dan regulator. OPZ adalah organisasi yang mengandalkan dana publik untuk menjalankan semua aktivitasnya. Sehingga aspek kepercayaan masyarakat (trust) menjadi sangat penting. Semakin tinggi tingkat kepercayaan masyarakat, maka semakin tinggi pula tingkat penghimpunan dana OPZ. Namun sayangnya hingga saat ini masih banyak muzaki yang belum percaya dengan OPZ, sehingga lebih memilih menyalurkan dana zakatnya secara langsung kepada mustahik.

Rendahnya kesadaran muzaki dalam menunaikan zakat secara benar sesuai syariat juga menjadi prioritas masalah zakat dari sisi muzaki. Salah satu contohnya adalah muzaki masih gemar menyalurkan zakat secara langsung kepada mustahik. Penyaluran zakat secara langsung dapat menimbulkan masalah baru.

Prioritas masalah selanjutnya adalah rendahnya pengetahuan muzaki tentang fikih zakat. Rendahnya pengetahuan tentang fikih zakat ini menyebabkan rendahnya kesadaran menunaikan zakat bagi para muzaki. Banyak muzaki yang tidak mengetahui apakah dirinya sudah wajib zakat atau belum, bagaimana pentingnya kedudukan zakat dalam agama Islam, bagaimana beratnya ancaman Allah bagi orang yang tidak menunaikan zakat, dan bagaimana cara menyalurkan zakat dengan benar.

\section{Prioritas solusi pengelolaan zakat}

Prioritas solusi regulator adalah: 1) keteladanan pejabat dalam menunaikan zakat sesuai syariat; 2) kewajiban audit eksternal; 3) meningkatkan fungsi pengaturan dan pengawasan; 4) meningkatkan peran Majelis Ulama Indonesia (MUI); 5) sertifikasi amil;dan 6) standarisasi dan akreditasi OPZ.

Prioritas solusi pengelolaan zakat pada regulator adalah dengan pemberian keteladanan dalam menunaikan zakat secara benar sesuai syariat. Para pemimpin, pejabat, termasuk juga pengelola zakat, para da'i harus memulai dari diri sendiri sebelum menyuruh orang lain berzakat. Contoh konkret lain terkait dengan sosialisasi zakat adalah dengan melakukan kampanye zakat baik di media elektronik, jejaring sosial, maupun media cetak.

Prioritas solusi selanjutnya adalah mengadakan kewajiban audit eksternal yang dilakukan oleh regulator zakat kepada OPZ. Kewajiban audit bagi setiap OPZ dapat meningkatkan penerapan good corporate governance (GCG) pada OPZ. peningkatan GCG dapat membantu meningkatkan transparansi dan akuntabilitas OPZ yang dapat membantu meningkatkan kepercayaan masyarakat terhadap OPZ. Selain itu, Regulator juga dianggap perlu melakukan fungsi pengaturan dan 
pengawasan kepada OPZ sebagaimana Bank Indonesia melakukan fungsi tersebut kepada perbankan. Jika ada OPZ yang berprestasi, maka regulator dapat memberikan penghargaan. Sebaliknya, jika OPZ tidak menjalankan perannya dengan baik, maka regulator dapat memberikan sanksi.

Meningkatkan peran Majelis Ulama Indonesia (MUI) dalam menyelesaikan persoalan khilafiyah fikih zakat juga dianggap sebagai prioritas solusi pengelolaan zakat. MUI sebagai wadah berkumpulnya para ulama yang diakui oleh pemerintah seharusnya dapat memberikan keputusan tentang perbedaan pendapat fikih zakat yang merebak di masyarakat.

Sertifikasi amil juga dianggap sebagai prioritas solusi permasalahan zakat nasional. Amil zakat sebagai ujung tombak pengeloaan zakat haruslah orang yang memiliki kapasitas yang cukup untuk mengemban amanah sebagaimana Rasulullah saw juga memilih sahabat-sahabat terbaik sebagai amil zakat. Sertifikasi amil dimaksudkan untuk menjamin kualitas amil sesuai dengan standar kompetensi yang dibutuhkan.

Prioritas solusi atas pengelolaan zakat terakhir dari sisi regulator yang ditemukan adalah standarisasi dan akreditasi OPZ. Standarisasi pengelolaan zakat dalam OPZ akan dapat memudahkan perbandingan kinerja antar OPZ. Sebagai contoh, jika semua OPZ menerapkan PSAK 109 yang merupakan standarisasi pengelolaan keuangan OPZ, maka hal tersebut akan membantu para auditor dalam membandingkan kinerja keuangan antar satu OPZ dengan OPZ lainnya.

Prioritas solusi OPZ adalah: 1) management training dan kerjasama dengan perguruan tinggi dalam memenuhi kebutuhan amil profesional; 2) membangun sinergi antar stakeholder zakat; 3) memperluas jaringan OPZ; 4) peningkatan efektifitas program pendayagunaan zakat; 5) peningkatan transparansi dan akuntabilitas; 6) standarisasi zakat nasional.

Prioritas solusi pengelolaan zakat pada OPZ pertama adalah dengan pengadaan manajemen pelatihan dan kerjasama dengan perguruan tinggi dalam memenuhi kebutuhan amil profesional. Managemen pelatihan adalah langkah jangka pendek yang dilakukan untuk memenuhi kebutuhan amil pada OPZ, sedangkan pembentukan kerja sama dengan perguruan tinggi adalah langkah jangka menengah dan panjang untuk menjamin stok amil profesional di masa yang akan datang.

Prioritas solusi pengelolaan zakat pada OPZ selanjutnya adalah pembangunan sinergi antar stakeholder zakat. Sinergi yang dapat dilakukan adalah dalam sosialisasi zakat, persamaan fikih zakat, standarisasi pengelolaan zakat, penyusunan data basemustahik dan muzaki, hingga sinergi dalam program pendayagunaan zakat 
di lapangan. Memperluas jaringan OPZ dianggap oleh sebagian informan sebagai prioritas solusi pengelolaan zakat pada OPZ. Menurut Wibisono (2011), saat ini terdapat 33 BAZDA provinsi, 447 BAZDA kabupaten/kota serta 18 LAZ nasional dan 22 LAZ daerah. Meski jaringan OPZ sudah cukup luas, perlu dilakukan peningkatan baik dari sisi kuantitas maupun kualitas jaringannya sehingga dapat semakin menjangkau mustahik/muzaki.

Peningkatan efektifitas program pendayagunaan zakat juga dianggap sebagai prioritas solusi pengelolaan zakat pada OPZ. program pendayagunaan yang dilakukan OPZ hendaknya dilakukan dengan prinsip tepat guna agar benar-benar dapat memberikan maslahat kepada mustahik. Selain itu OPZ dianggap perlu menjaga program pendayagunaannya agar tetap berjalan dengan baik meski sudah ditinggal oleh OPZ.

Peningkatan transparansi dan akuntabilitas dipandang perlu dimasukan sebagai prioritas solusi pengelolaan zakat pada OPZ. Transparansi adalah keterbukaan dalam pengelolaan keuangan, sedangkan akuntabilitas yang dimaksud adalah ketersesuaian antara rencana dengan pelaksanaan keuangan. Pengelolaan keuangan yang transparan dan akuntabel pada akhirnya dapat menimbulkan kepercayaan masyarakat terhadap OPZ.

Prioritas solusi pengelolaan zakat pada OPZ terakhir yang diungkap adalah standarisasi zakat nasional. Standarisasi zakat nasional yang dimaksud adalah penyamaan standar pengelolaan zakat pada OPZ. Pengelola zakat dianggap perlu melakukan standarisasi pada aspek-aspek lain seperti standarisasi fikih zakat.

Prioritas solusi muzaki/mustahik adalah: 1) kaderisasi dai zakat; 2) kemudahan layanan; 3) perbaikan materi zakat dalam pelajaran sekolah; 4) pemberian penghargaan bagi yang menunaikan zakat dan hukuman (punishment) bagi yang tidak menunaikan zakat padahal telah wajib zakat; 5) pengingkatan sosialisasi dan edukasi zakat kepada masyarakat; dan 6) menjadikan zakat sebagai gaya hidup masyarakat.

Gambar 2. Struktur Jaringan AHP

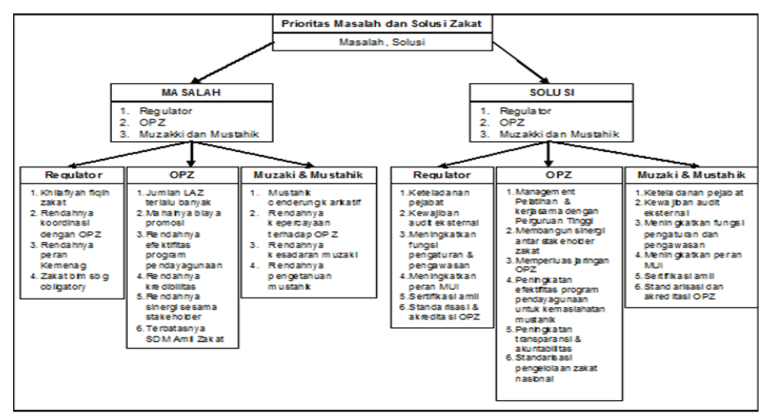

Sumber: wawancara, data diolah. 
Prioritas solusi pengelolaan zakat pada muzaki/mustahik pertama yang dikemukakan adalah kaderisasi dai zakat. Belum banyak dai/ustadz yang menyampaikan tentang fikih zakat, akibatnya ummat Islam tidak faham akan pentingnya zakat. Diharapkan dengan kaderisasi dai zakat, syiar zakat akan semakin tersebar melalui mimbar-mimbar Jumat, ceramah baik di media cetak atau elektronik.

Prioritas solusi selanjutnya adalah meningkatkan kemudahan layanan zakat. Kemudahan berzakat yang menjangkau berbagai lapisan masyarakat diharapkan dapat meningkatkan penghimpunan zakat. Pemberian materi zakat dalam pelajaran sekolah juga dianggap sebagai salah satu prioritas solusi pengelolaan zakat pada muzaki/mustahik. Selain itu pemberian penghargaan bagi wajib zakat yang membayar zakat dan sanksi bagi wajib zakat yang tidak membayar zakat juga merupakan prioritas solusi yang dianggap dapat menjadi salah satu langkah pemecahan masalah pengelolaan zakat.

Peningkatan sosialisasi dan edukasi zakat kepada masyarakat merupakan prioritas solusi yang dianggap sangat penting dalam menyelesaikan permasalahan zakat nasional. Sosialisasi dapat memberikan pemahaman kepada masyarakat tentang pentingnya zakat. Pemahaman memberikan kesadaran dan kesadaran akan memberikan dorongan yang lebih kuat untuk berzakat.

Prioritas solusi terakhir yang ditawarkan para informan dalam menyelesaikan permasalahan zakat adalah menjadikan zakat sebagai gaya hidup masyarakat. Zakat diharapkan dapat menjadi gaya hidup masyarakat sebagaimana masyarakat modern yang sudah menggunakan asuransi sebagai gaya hidup.

Semua aspek di atas jika dikonstruksi menjadi model AHP maka akan tampak pada gambar 2 berikut. Gambar 2 adalah model dibangun dengan metode AHP. Model ini bersifat hierarkis. Pada model AHP seluruh hubungan yang terbentuk selalu berawal dari node (simpul) atas ke node bawah (top down).

\section{Hasil kuantifikasi model}

Setelah model AHP terbentuk, tahapan selanjutnya adalah mengkuantifikasi model dengan melakukan perbandingan berpasangan (pairwise comparison). Hasil yang pairwise comparison dari kedua model di atas ditampilkan dalam tabel-tabel di bawah ini. Tabel 1 menggambarkan perbandingan antara nilai skor prioritas model AHP Banten dan Kalsel dalam penentuan prioritas masalah pengelolaan zakat secara keseluruhan. Tampak bahwa lembaga paling bermasalah dalam pengelolaan zakat menurut model AHP Banten adalah regulator. Begitu pula dengan model AHP Kalsel yang menyatakan bahwa lembaga paling bermasalah dalam pengelolaan zakat adalah regulator. Menurut model AHP baik yang dilakukan di Banten maupun Kalsel, prioritas masalah regulator adalah rendahnya peran kementerian agama 
(Kemenag).

Prioritas masalah OPZ adalah rendahnya sinergi sesama stakeholder zakat. Baik model AHP Banten maupun Kalsel menghasilkan sintesa hasil prioritas yang sama. Hal ini sesuai dengan Hafidhuddin dan Juwaini (2006), dimana sinergi antar OPZ terutama antara lembaga zakat bentukan pemerintah (BAZ) dengan lembaga zakat bentukan masyarakat (LAZ) belum terjadi dengan baik. Akibatnya, banyaknya OPZ bukan menjadi sarana untuk membantu pemerintah dalam mengentaskan kemiskinan, tapi justru menjadi penyebab tumbuhnya persaingan yang tidak sehat antara organisasi.

Tabel 1. Perbandingan Nilai Skor Prioritas Antara Model AHP Banten Dan Kalsel

Dalam Penentuan Prioritas Masalah Pengelolaan Zakat Secara Keseluruhan

\begin{tabular}{|c|c|c|c|c|c|}
\hline Lembaga & Banten & Kalsel & Aspek & Banten & Kalse \\
\hline \multirow{4}{*}{ Regulator } & \multirow{4}{*}{0,631} & \multirow{4}{*}{0,588} & 1. Khilafiyah fiqih zakat & 0,134 & 0,270 \\
\hline & & & 2. Rendahnya koordinasi dgn OPZ & 0,321 & 0,288 \\
\hline & & & 3. Rendahnya peran Kemenag & 0,366 & 0,339 \\
\hline & & & $\begin{array}{l}\text { 4. Zakat belum sebagai obligatory } \\
\text { sistem }\end{array}$ & 0,179 & 0,103 \\
\hline \multirow{6}{*}{ OPZ } & \multirow{6}{*}{0,121} & \multirow{6}{*}{0,297} & 1. Jumlah LAZ terlalu banyak & 0,042 & 0,101 \\
\hline & & & 2. Mahalnya biaya promosi & 0,130 & 0,064 \\
\hline & & & $\begin{array}{l}\text { 3. Rendahnya efektifitas program } \\
\text { pedayagunaan }\end{array}$ & 0,115 & 0,101 \\
\hline & & & 4. Rendahnya kredibilitas & 0,082 & 0,101 \\
\hline & & & $\begin{array}{l}\text { 5. Rendahnya sinergi sesama } \\
\text { stakeholder }\end{array}$ & 0,316 & 0,316 \\
\hline & & & 6. Terbatasnya SDM Amil & 0,315 & 0,316 \\
\hline \multirow{4}{*}{$\begin{array}{l}\text { Muzaki dan } \\
\text { mustahik }\end{array}$} & \multirow{4}{*}{0,248} & \multirow{4}{*}{0,134} & 1. Mustahik cenderung karikatif & 0,105 & 0,105 \\
\hline & & & $\begin{array}{l}\text { 2. Rendahnya kepercayaan } \\
\text { terhadap OPZ dan regulator }\end{array}$ & 0,138 & 0,284 \\
\hline & & & 3. Rendahnya kesadaran muzaki & 0,380 & 0,287 \\
\hline & & & 4. Rendahnya pengetahuan muzaki & 0,378 & 0,324 \\
\hline
\end{tabular}

Sumber: hasil penelitian, data diolah.

Model AHP Banten menyatakan bahwa prioritas masalah mustahik dan muzaki adalah rendahnya kesadaran muzaki, adapun model AHP Kalsel menganggap bahwa prioritas masalah muzaki adalah rendahnya pengetahuan muzaki. Rendahnya pengetahuan muzaki tentang fikih zakat mengakibatkan rendahnya kesadaran bayar zakat. Banyak orang wajib zakat yang tidak bayar zakat lantaran tidak mengetahui 
kewajiban zakat. Mungkin inilah yang menyebabkan realisasi penghimpunan zakat baru mencapai kurang dari 2\% dari total potensinya pada tahun 2012. Rendahnya pengetahuan fikih zakat bagi muzaki juga menyebabkan praktik pembayaran zakat yang tidak sesuai dengan syariat. Kekeliruan yang paling umum dijumpai adalah praktik pemberian zakat secara langsung kepada mustahik. Akibatnya, mustahik cenderung karikatif/konsumtif dan sering terjadi korban meninggal akibat berdesak-desakan berebut zakat. selain itu juga, pemberian zakat secara langsung tidak sesuai dengan semangat pemberdayaan masyarakat yang menjadi kunci untuk pengentasan kemiskinan. Jika melihat pada hasil yang didapat, diantara metode AHP Banten dengan model AHP Kalsel terdapat banyak kemiripan prioritas. Hal ini dikarenakan adanya kesamaan struktur konstruksi model yang dibentuk.

Hasil pairwise comparison selanjutnya adalah prioritas solusi pengelolaan zakat. Perbandingan nilai skor prioritas solusi antara model AHP Banten dan Kalsel disajikan dalam tabel 2. Pada tabel 2 tampak bahwa antara metode AHP Banten dan Kalsel menyatakan bahwa lembaga yang paling diandalkan dalam pemecahan masalah (problem solver) pengelolaan zakat adalah regulator. Baik model AHP Banten maupun Kalsel menyatakan bahwa prioritas solusi regulator adalah sertifikasi amil. Prioritas solusi OPZ menurut model AHP Banten dan Kalsel adalah perbaikan materi/kurikulum zakat dalam pelajaran sekolah. Berdasarkan uraian di atas, tampak bahwa hasil prioritas antara model AHP Banten dan Kalsel memiliki banyak kesamaan hasil (priorities).

Tabel 2. Perbandingan Prioritas Solusi Antara Model AHP Banten Dan Kalsel Penentuan Prioritas Solusi Pengelolaan Zakat Secara Keseluruhan

\begin{tabular}{|c|c|c|c|c|c|}
\hline Lembaga & Banten & Kalsel & Aspek & Banten & Kalsel \\
\hline \multirow{6}{*}{ Regulator } & \multirow{6}{*}{0,467} & \multirow{6}{*}{0,549} & 1. Keteladanan pejabat & 0,205 & 0,142 \\
\hline & & & 2. Kewajiban audit eksternal & 0,205 & 0,242 \\
\hline & & & $\begin{array}{l}\text { 3. Meningkatkan fungsi } \\
\text { pengaturan dan pengawasan }\end{array}$ & 0,072 & 0,113 \\
\hline & & & 4. Meningkatkan peran MUI & 0,064 & 0,113 \\
\hline & & & 5. Sertifikasi amil & 0,382 & 0,317 \\
\hline & & & $\begin{array}{l}\text { 6. Standarisasi dan akreditasi } \\
\text { OPZ }\end{array}$ & 0,072 & 0,073 \\
\hline
\end{tabular}




\begin{tabular}{|c|c|c|c|c|c|}
\hline \multirow{7}{*}{ OPZ } & \multirow{7}{*}{0,322} & \multirow{7}{*}{0,308} & 1. Management Training dan & & \\
\hline & & & Tinggi & 0,206 & 0,101 \\
\hline & & & $\begin{array}{l}\text { 2. Membangun sinergi antar } \\
\text { stakeholder zakat }\end{array}$ & 0,243 & 0,271 \\
\hline & & & 3. Memperluas jaringan OPZ & 0,078 & 0,064 \\
\hline & & & $\begin{array}{l}\text { 4. Peningkatan efektifitas } \\
\text { program pendayagunaan utk } \\
\text { kemaslahatan mustahik }\end{array}$ & 0,135 & 0,147 \\
\hline & & & $\begin{array}{l}\text { 5. Peningkatan transparansi } \\
\text { dan akuntabilitas }\end{array}$ & 0,156 & 0,271 \\
\hline & & & $\begin{array}{l}\text { 6. Standarisasi pengelolaan } \\
\text { zakat nasional }\end{array}$ & 0,181 & 0,147 \\
\hline \multirow{6}{*}{$\begin{array}{l}\text { Muzaki dan } \\
\text { mustahik }\end{array}$} & \multirow{6}{*}{0,211} & \multirow{6}{*}{0,143} & 1. Kaderisasi dai zakat & 0,157 & 0,223 \\
\hline & & & 2. Kemudahan layanan & 0,100 & 0,162 \\
\hline & & & $\begin{array}{l}\text { 3. Perbaikan materi zakat } \\
\text { dalam pelajaran sekolah }\end{array}$ & 0,266 & 0,253 \\
\hline & & & 4. Reward dan punishment & 0,043 & 0,244 \\
\hline & & & 5. Sosialisasi dan edukasi & 0,215 & 0,064 \\
\hline & & & 6. Zakat sbg lifestyle & 0,221 & 0,053 \\
\hline
\end{tabular}

Sumber: hasil penelitian, data diolah.

\section{SIMPULAN}

Terdapat tiga macam prioritas masalah dan solusi pengelolaan zakat yang dibagi berdasarkan lembaga pemangku kepentingan (stakeholder) pengelolaan zakat, yaitu regulator, organisasi pengelola zakat (OPZ), serta muzaki dan mustahik zakat. Lembaga paling bermasalah dalam pengelolaan zakat menurut model AHP Banten dan Kalsel adalah regulator. Baik menurut model AHP Banten ataupun Kalsel, prioritas masalah regulator adalah rendahnya peran Kemenag. Prioritas masalah OPZ adalah rendahnya sinergi sesama stakeholder zakat. Menurut model AHP Banten, prioritas masalah mustahik/muzaki adalah rendahnya kesadaran muzaki, sedangkan menurut model AHP Kalsel adalah rendahnya pengetahuan muzaki.

Model AHP yang dilakukan baik di Banten dan Kalsel menghasilkan skor prioritas yang sama, bahwa lembaga yang paling diandalkan dalam pemecahan masalah (problem solver) pengelolaan zakat adalah OPZ dan prioritas solusi regulator adalah sertifikasi amil. Demikian pula menurut kedua model tersebut prioritas solusi OPZ adalah membangun sinergi antar stakeholder zakat dan prioritas solusi 
muzaki/mustahik adalah perbaikan materi zakat dalam pelajaran sekolah.

Meskipun menggunakan dua objek penelitian yang berbeda, ternyata hasil prioritas antara model AHP provinsi Banten dan Kalsel memiliki banyak kesamaan hasil (priorities). Hal ini kemungkinan dipengaruhi oleh adanya kemiripan jaringan model dalam connecxions (hubungan) antar node (simpul) yang telah terbentuk di dalam software superdecisions.

\section{PUSTAKA ACUAN}

Abduh, M. 2013. Apa yang Menjadi Prioritas Isu dalam Keuangan Syariah?. Jakarta: Rubrik Iqtishodia Harian Republika, Edisi 31, Oktober 2013.

Anriani. 2010. BAZ Kota Bogor dan Pengentasan Kemiskinan. Jurnal Ekonomi Islam Republika, 29 Juli 2010.

Ascarya. 2012. Konsep Dasar ANP: Pendekatan Baru dalam Penelitian Kualitatif. Jakarta: Pusat Pendidikan dan Studi Kebanksentralan Bank Indonesia.

BAZNAS dan FEM IPB. 2011. Economic Estimation and Determinans of Zakah Potential in Indonesia. Preliminary Report.

Beik, I.S. 2009. Analisis Peran Zakat dalam Mengurangi Kemiskinan: Studi Kasus Dompet Dhuafa Republika. Jurnal Pemikiran dan Gagasan Vol II, Institut Manajemen Zakat.

Hartoyo, S dan N. Purnamasari. 2010. Pengentasan Kemiskinan Berbasis Zakat: Studi Kasus di Garut. Jurnal Ekonomi Islam Republika, 29 Juli 2010.

Indrijatiningrum, M. 2005. Zakat Sebagai Alternatif Penggalangan Dana Masyarakat untuk Pembangunan (Tesis). Jakarta: Universitas Indonesia.

Kahf, Monzer. 1987. Report on Zakat and Ushr Fund Management in the Islamic Republic of Pakistan. Islamabad: IRTI, Islamic Development Bank and International Institute of Islamic Economics, International Islamic University.

Mintarti, Nana. 2012. Membangun Kepercayaan Publik dan Kapasitas Pengelolaan Zakat di Indonesia. http://www.imz.or.id, diunduh 21 November 2012.

Qardhawi, Y. 2007. Hukum Zakat. Bogor: Pustaka Litera AntarNusa.

Saaty, T.L. 1991. Pengambilan Keputusan Bagi Para Pemimpin, Proses Hirarki Analitik untuk Pengambilan Keputusan dalam Situasi yang Kompleks. Jakarta: PT. Pustaka Binaman Pressindo.

1994 Fundamentals of Decision Making and Priority Theory with Analytic Hierarchy Process. Journal, Vol. VI of the AHP Series. Pittsburgh, U.S.A. 1994.

2004. Decision Making-The Analytic Hierarchy and Network Processes (AHP/ANP). Journal of systems science \& systems engineering 13 (1) March 
2004: page. 1-35. 2004

2008. Decision Making with The Analytic Hierarchy Process. Int. Journal Services Sciences, Vol. 1, No. 1, 2008. 2008

Saaty, T. L and L.G. Vargas. 2006. Decision Making with The Analytic Network Process. USA: Springer.

Sabiq, S. 2006. Fiqh Sunnah: Jilid 1, Jilid 2, dan Jilid 4. Jakarta: Pena Pundi Aksara.

Tsani, T. 2010. Mengentaskan Kemiskinan dan Kesenjangan di Lampung Selatan. Jurnal Ekonomi Islam Republika, 26 Juli 2010. 